\title{
Comparing high-resolution gridded precipitation data with satellite rainfall estimates of TRMM_3B42 over Iran
}

\author{
S. Javanmard ${ }^{1,2}$, A. Yatagai $^{1}$, M. I. Nodzu ${ }^{1}$, J. BodaghJamali ${ }^{1,2}$, and H. Kawamoto ${ }^{1}$ \\ ${ }^{1}$ Research Institute for Humanity and Nature (RIHN), Kyoto 603-8047, Japan \\ ${ }^{2}$ Atmospheric Science and Meteorological Research Center (ASMERC), I. R. of Iran Meteorological Organization (IRIMO), \\ Tehran 14965-114, Iran
}

Received: 5 September 2009 - Revised: 18 April 2010 - Accepted: 19 April 2010 - Published: 17 May 2010

\begin{abstract}
To evaluate satellite rainfall estimates of Tropical Rain Measurement Mission (TRMM) level 3 output (3B42) (TRMM_3B42) over Iran $\left(20^{\circ}-45^{\circ} \mathrm{N}, 40^{\circ}-65^{\circ} \mathrm{E}\right)$, we compared these data with high-resolution gridded precipitation datasets $\left(0.25^{\circ} \times 0.25^{\circ}\right.$ latitude/longitude) based on rain gauges (Iran Synoptic gauges Version 0902 (IS0902)). Spatial distribution of mean annual and mean seasonal rainfall in both IS0902 and TRMM_3B42 from 1998 to 2006 shows two main rainfall patterns along the Caspian Sea and over the Zagros Mountains. Scatter plots of annual average rainfall from IS0902 versus TRMM_3B42 for each $0.25^{\circ} \times 0.25^{\circ}$ grid cell over the entire country $\left(25^{\circ}-40^{\circ} \mathrm{N}\right.$, $\left.45^{\circ}-60^{\circ} \mathrm{E}\right)$, along the Caspian Sea $\left(35^{\circ}-40^{\circ} \mathrm{N}, 48^{\circ}-56^{\circ} \mathrm{E}\right)$, and over the Zagros Mountains $\left(28^{\circ}-37^{\circ} \mathrm{N}, 46^{\circ}-55^{\circ} \mathrm{E}\right)$ were derived. For the entire country, the Caspian Sea region, and the Zagros Mountains, TRMM_3B42 underestimates mean annual precipitation by $0.17,0.39$, and $0.15 \mathrm{~mm}$ day $^{-1}$, respectively, and the mean annual rainfall spatial correlation coefficients are $0.77,0.57$, and 0.75 , respectively. The mean annual precipitation temporal correlation coefficient for IS0902 and TRMM_3B42 is $\sim 0.8$ in the area along the Zagros Mountains, and $\sim 0.6$ in the Caspian Sea and desert regions.
\end{abstract}

\section{Introduction}

Global precipitation is a major component of the global water and energy cycle that influences significantly Earth's climate system, and in is turn affected by climate system variability and change. The Radiation Panel of the Global En-

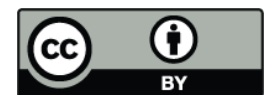

Correspondence to: S. Javanmard (sohailajavanmard@gmail.com) ergy and Water Cycle experiment (GEWEX) of the World Climate Research Programme (WCRP) was formed to improve understanding of seasonal and inter-annual and longerterm variability of the global hydrological cycle, to determine the atmospheric latent heat rates needed for weather and climate prediction models, and to provide an observational precipitation data set for model validation, initialization and other hydrological applications (Gruber and Levizzani, 2008). Many attempts have been conducted to develop and improve global and regional gridded precipitation gauge data sets in recent years (e.g. New et al., 2000; Mitchell and Jones, 2005; Schneider, 2008). However, due to the lack of observational precipitation datasets over land areas for most of Asia, Yatagai et al. $(2008,2009)$ have created a highresolution rain gauge-based daily precipitation grid dataset for East, Middle East, and Russia. To achieve more accurate gridded precipitation data over Iran, Javanmard et al. (2008) presented the improvement of gridded precipitation data over Iran using highly quality-controlled data from $\sim 200$ synoptic stations of the Islamic Republic of Iran Meteorological Organization (IRIMO).

Although rain gauge observations provide longer records (Yatagai et al., 2009) they do not provide a reliable spatial representation of precipitation (Gruber and Levizzani, 2008). For example, the distribution of gauge networks is sparse in desert and mountainous areas in Iran. Remote sensing techniques, such as those using radar or satellites, are useful for monitoring rainfall over large mountainous and oceanic regions, and their time series accuracy and precision being potentially locally be lower than existing and corresponding data sets derived from ground-based measurements, they provide more homogeneous data quality compared ground observations (Schulz et al., 2009) they. Satellites-based data sets need to be examined and verified by comparison with ground-based rain gauge data. Xie et al. (2007) verified

Published by Copernicus Publications on behalf of the European Geosciences Union. 


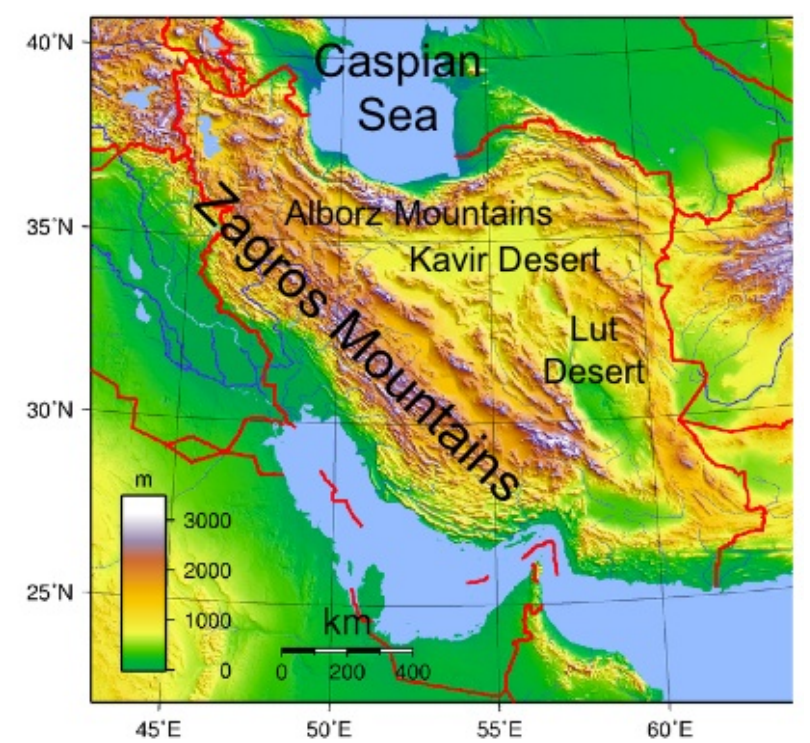

Fig. 1. Topographic map of Iran.

the performance of five satellite-based high-resolution precipitation outputs by comparison against gauge analysis: TRMM (3B42, 3B42RT )(Huffman et al., 2004; Huffman et al., 2007), National Weather Service, USA (NWS), Climate Prediction Center (CPC), Morphing Techniques (CMORPH; Joyce et al., 2004), Precipitation Estimation from Remotely Sensed Information using Artificial Neural Networks (PERSIANN; Sorooshian et al. 2000), Naval Research Laboratory (NRL; Turk et al., 2004). They found that all satellite data performed better in depicting precipitation for wet climate regions and wet seasons, but were limited skills in estimating precipitation over central Asian arid and semi-arid regions. The performance of satellite-based precipitation has not been verified over arid and semi-arid areas in Iran. To address this, in this paper we compare rainfall estimates of TRMM_3B42 with gauge-based high-resolution gridded precipitation data over Iran from 1998 to 2006 to evaluate and verify TRMM-based precipitation outputs.

\section{Data and methods}

\subsection{Study area}

Iran lies in the world's dry belt. Iran $\left(25^{\circ}-40^{\circ} \mathrm{N}, 45^{\circ}-60^{\circ} \mathrm{E}\right)$ is one of the most mountainous countries bordering the Gulf of Oman, the Persian Gulf, and the Caspian Sea. Sixty percent of Iran is covered by mountains. The central parts of the country comprise two dry deserts: the Dasht-e-Kavir and the Dasht-e-Lut. The country's topography is dominated by two mountain ranges. The Alborz range in the north, close to the Caspian Sea extends east-west with a maximum altitude of $\sim 5000 \mathrm{~m}$. The Zagros Mountains cross the country

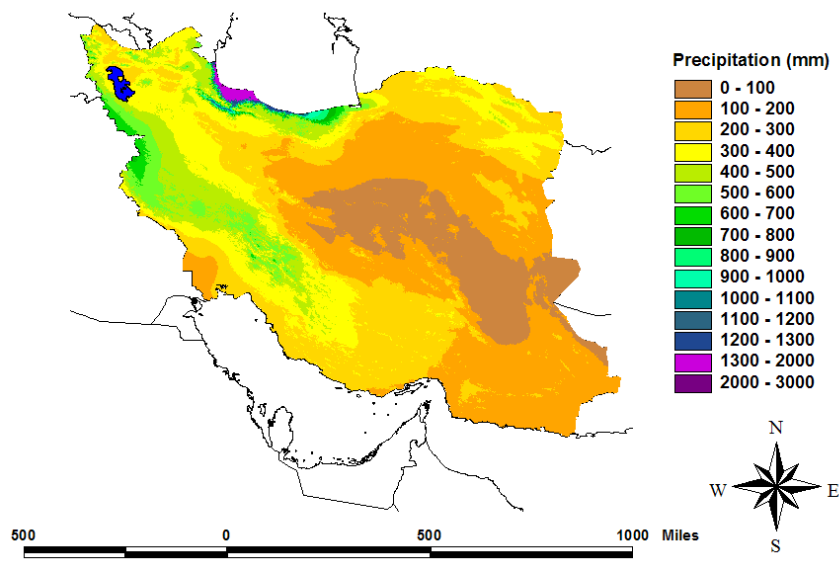

Fig. 2. Mean annual precipitation (mm) across Iran from 1961 to 1990.

from northwest to southeast and reach a maximum altitude of $\sim 3500 \mathrm{~m}$ (Fig. 1). These two ranges play an influential role in determining the amount and distribution of rainfall over the country. The dominant flow directions of air masses are from the west and from the south. Several air masses influence Iran throughout the year. The major ones are the Mediterranean low-pressure system which flows from the west throughout the year, the Siberian high-pressure system (Siberian High) which flows into the country from the north mostly during the winter, and the Sudan tropical low pressure (Sudan Low) which flows from the southwest (Golestani, 2000). Iran is classified generally as arid or semiarid with mean annual rainfall $\sim 250 \mathrm{~mm}$ for the entire country, ranging from $50 \mathrm{~mm}$ in the deserts to $1600 \mathrm{~mm}$ on the Caspian coast (Fig. 2).

The rainy period for most of the country is from November to May, during which the average rainfall is $\sim 240 \mathrm{~mm}$. Maximum precipitation falls on the Alborz and Zagros slopes, facing north and west, respectively, where the mean annual rainfall is $>1200 \mathrm{~mm}$. Farther inland, the precipitation decreases to $<100$ or $<50 \mathrm{~mm}$ annually. Precipitation varies considerably with topography. In the northern and western mountains the annual mean precipitation is $>480 \mathrm{~mm}$. The plateau receives most of the rainfall in spring, while on the western and southern coasts most rain falls in winter. On the Caspian coast where the rain falls earlier, maximum rainfall is in autumn. In the dry period between May and October, rain is rare in most of the country. Ninety percent of total precipitation occurs during the cold and humid seasons in the northern and western parts of the country, and only $10 \%$ occurs during the warm and dry seasons and in the central, southern and eastern regions. Fifty-two percent of precipitation falls on $25 \%$ of the country's land area; resulting in a lack of water resources and potential water crises in the near future. 


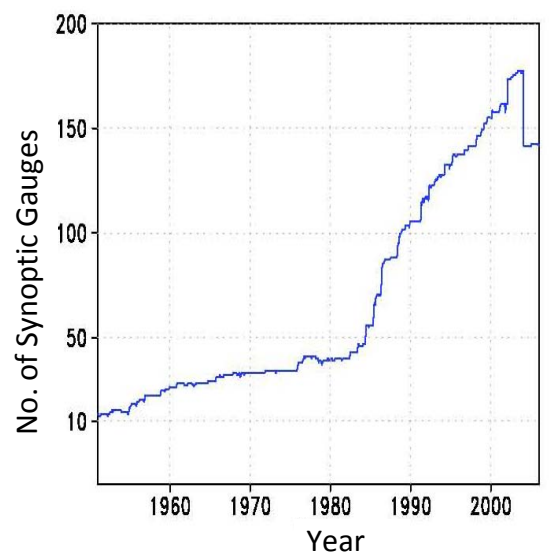

Fig. 3. Time series of the number of synoptic gauges used in this study.

\subsection{Synoptic gauge-network data of the Islamic Republic of Iran Meteorological Organization}

The surface-based data used in this study are synoptic gauge data of the Islamic Republic of Iran Meteorological Organization (IRIMO). Figure 3 shows time series of the number of synoptic gauges over Iran. The number of synoptic stations used in this study varies from a maximum of 188 in 2004 to a minimum of $10 \mathrm{in} 1951$. There is a yearly increase, and the mean number of gauges for the analysis period is 130 (Fig. 3). The synoptic gauge data have passed IRIMO quality control procedures such as checking location (latitude, longitude and elevation), consistency with other meteorological parameters, tests for data homogeneity, filling data gaps. Figure 3 also shows a significant increase in number of synoptic gauges from 1985 onwards. Figure 4 shows the spatial distribution of the synoptic gauge stations over Iran, with mean station numbers in 0.25-degree-grid cells averaged for nine years from 1998 to 2006. The distribution of synoptic gauges is denser in along the Zagros Mountains, the Caspian coast and in the north-western regions than in the desert regions.

\subsection{TRMM and other satellite data (TRMM_3B42)}

The Tropical Rainfall Measuring Mission (TRMM) is a joint US-Japan program to measure tropical and subtropical rainfall using the following instruments: Precipitation Radar (PR), TRMM Microwave Imager (TMI), and the Visible and Infrared Scanner (VIRS) (NASDA, 2001). The input for the Ver. 6 TRMM and other satellites (3B42) consists o: (1) TRMM High Quality (HQ) combined microwave precipitation estimates of TRMM Combined Instrument (TCI), TMI, Special Sensor Microwave/Imager (SSM/I), Advanced Microwave Scanning Radiometer for EOS (AMSR-E) on board EOS Aqua, and the Advanced Microwave Sounding Unit B (AMSU- B) onboard the National Oceanic and Atmospheric Administration - $14(\mathrm{~K}), 16(\mathrm{~L})$ and -17 (M) (NOAA
No. of Synoptic Gauges

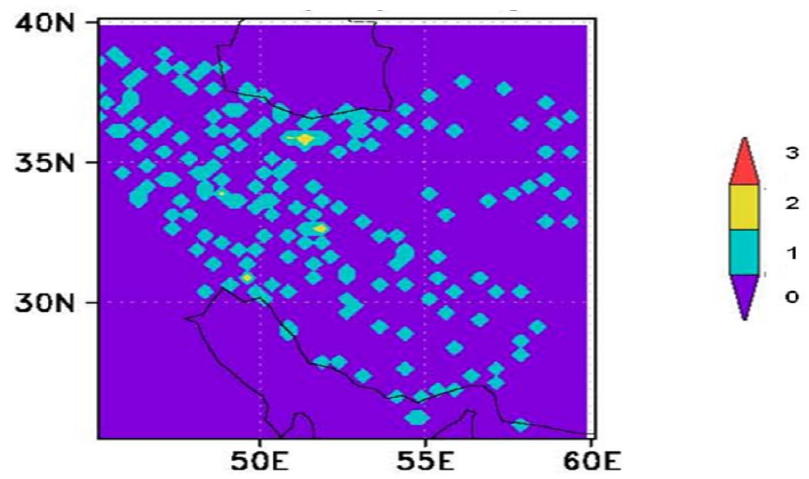

Fig. 4. Spatial distribution of annual average of number of synoptic gauges for $0.25^{\circ} \times 0.25^{\circ}$ grid cells over Iran (1998-2006).

KLM) satellites; (2) The TRMM Variable Rain Rate precipitation algorithm (VAR) microwave-calibrated Infrared (IR); (3) Global Precipitation Climatology Centre (GPCC) or Climate Analysis and Monitoring System (CAMS) gauge analyses (Huffman, 2006). In Ver. 6 of the 3B42 data set, GPCC monitoring data were used through March 2005 and CAMS thereafter (Huffman and Bolvin, 2008). The detailed TRMM_3B42 estimation procedure is described at the website http://trmm.gsfc.nasa.gov/3b42.html (last access: 15 December 2009.

The TRMM_3B42 precipitation output comprises $0.25^{\circ} \times 0.25^{\circ}$ grid cells for every $3 \mathrm{~h}$, with spatial extent covering a global belt $\left(-180^{\circ} \mathrm{W}\right.$ to $\left.180^{\circ} \mathrm{E}\right)$ extending from $50^{\circ} \mathrm{S}$ to $50^{\circ} \mathrm{N}$ latitude. In this paper, we used TRMM_3B42 data covering Iran from 1998 to 2006.

\subsection{Algorithm of daily gauge-based gridded precipitation data over Iran}

The procedure for deriving gridded precipitation data from daily gauges is based on Yatagai et al. (2008), and is as follows:

1. Define monthly precipitation for stations where data are available for $\geq 30$ years (selected from 337 IRIMO climatology stations);

2. Interpolate (1) into $0.05^{\circ}$ grid using the algorithm of Shepard (1968);

3. Define daily precipitation for stations where data are available for more than five years;

4. Apply a low-pass filter for daily precipitation by taking the first six harmonics of the Fourier transform in step (3).

5. Interpolate (4) to a $0.05^{\circ}$ grid using Shepard's (1968) algorithm, 


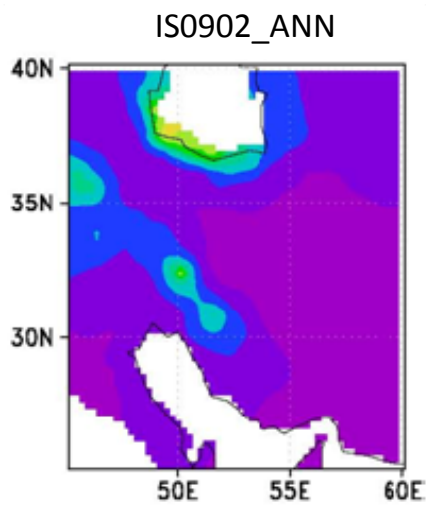
TRMM_3B42_ANN (mm/day)

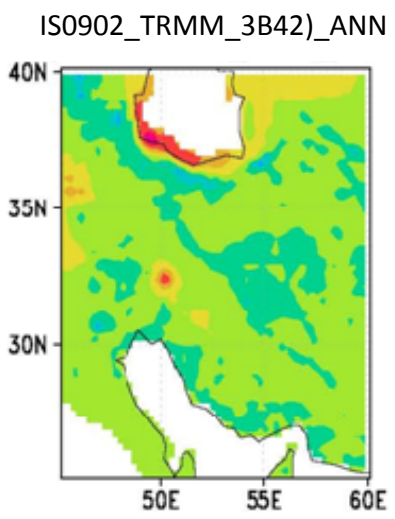

(mm/day)
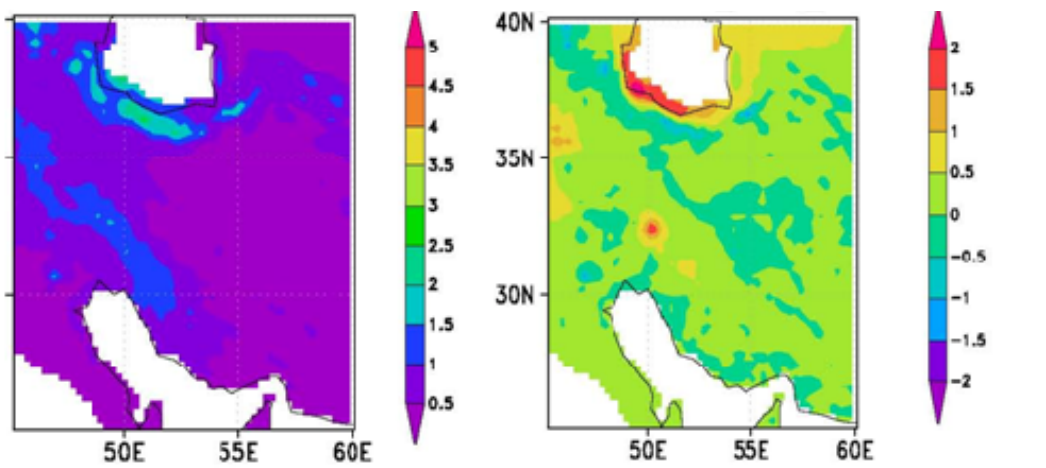

Fig. 5. Comparison of mean annual precipitation in IS0902 $\left(0.25^{\circ} \times 0.25^{\circ}\right)$ and TRMM 3 B $42\left(0.25^{\circ} \times 0.25^{\circ}\right)$ for the time period $1998-2006$. (a) IS0902 (mm day $\left.{ }^{-1}\right)$ and (b) TRMM_3B42 (mm day $\left.{ }^{-1}\right)$, (c) Difference in mean annual precipitation between IS0902 and TRMM_3B42 $\left(\mathrm{mmday}^{-1}\right)$. ANN = annual.

6. Adjust daily precipitation (5) to monthly precipitation (2);

7. Interpolate the ratio of daily precipitation from IRIMO synoptic stations to daily climatology (5) into the $0.05^{\circ}$ grid cell. Then multiply the interpolated ratio by the daily climatology in the corresponding grid to obtain gridded daily precipitation in the $0.05^{\circ}$ grid cell. Finally, precipitation values in $0.25^{\circ}$ and $0.5^{\circ}$ degree grids are derived from precipitation values in the $0.05^{\circ}$ grid.

\section{Results of comparison between IS0902 and TRMM_3B42}

\subsection{Spatial comparison}

\subsubsection{Spatial distribution of annual average of rainfall}

Figure 5 shows mean annual precipitation in a $0.25^{\circ}$ grid for the nine years from 1998 to 2006 . There is good accordance in precipitation pattern (Fig. 5a and b). The maximum mean annual rainfall in IS0902 (gridded precipitation from Iran Synoptic gauges Ver. 0902) is $3.5 \mathrm{~mm} \mathrm{day}^{-1}$ (Fig. 5a) and for TRMM_3B42 is $2.0 \mathrm{~mm} \mathrm{day}^{-1}$ (Fig. 5b). TRMM_3B42 underestimates precipitation along the Caspian Sea and the Zagros Mountains area by a maximum of $2.0 \mathrm{~mm} \mathrm{day}^{-1}$ (Fig. 5c).

\subsubsection{Spatial distribution of mean winter rainfall}

Because Iran receives rainfall mostly during winter (December-January-February (DJF)), we selected the winter rainfall distribution to compare to satellite data.
Comparison of mean winter precipitation betweenIS0902 $\left(0.25^{\circ} \times 0.25^{\circ}\right)$ and TRMM_3B42 $\left(0.25^{\circ} \times 0.25^{\circ}\right)$ for the 1998-2006 period is shown in Fig. 6. Maximum mean winter precipitation in IS0902 is $6 \mathrm{~mm} \mathrm{day}^{-1}$ (Fig. 6a) and for TRMM_3B42 is $4.0 \mathrm{~mm} \mathrm{day}^{-1}$ in Fig. 6b. TRMM_3B42 underestimates rainfall along the Zagros Mountains and the Caspian Sea compared with IS0902, with a maximum underestimation of $>2.0 \mathrm{~mm} \mathrm{day}^{-1}$ (Fig. 6c).

\subsection{Statistical comparison}

Using the $0.25^{\circ} \times 0.25^{\circ}$ data set of annual rainfall means in IS0902 and TRMM_3B42 (1998-2006), a scatter plot of IS0902 versus TRMM_3B42 for three regions is presented in Fig. 7a, b and c. The three regions are: the entire country $\left(25^{\circ}-40^{\circ} \mathrm{N}, 45^{\circ}-60^{\circ} \mathrm{E}\right)$, along the Caspian Sea $\left(35^{\circ}-\right.$ $\left.40^{\circ} \mathrm{N}, 48^{\circ}-56^{\circ} \mathrm{E}\right)$, and the Zagros Mountains $\left(28^{\circ}-37^{\circ} \mathrm{N}\right.$, $\left.46^{\circ}-55^{\circ} \mathrm{E}\right)$.

Statistical parameters derived in linear regression and the spatial correlation coefficients between mean annual rainfall in IS0902 and TRMM_3B42 are presented in Table 1. Spatial correlation coefficients for the above-mentioned regions are $0.77,0.57,0.75$, respectively, with significance level of derived spatial correlations of $99 \%$. The number of samples shown in Table 1 refers to the number of grid cells used for spatial correlation. Figure 8 shows the spatial distribution of temporal correlation coefficient of mean annual rainfall in IS0902 and TRMM_3B42 from 1998 to 2006. TRMM_3B42 has high accordance (correlation coefficient. >0.7) with IS0902 in the northwest region and along the Zagros Mountains, and has low accordance (correlation. coefficient <0.7) with IS0902 in most part of the desert regions along the Caspian Sea. This result accords well with derived spatial correlations for the three regions, as shown in Table 1. 

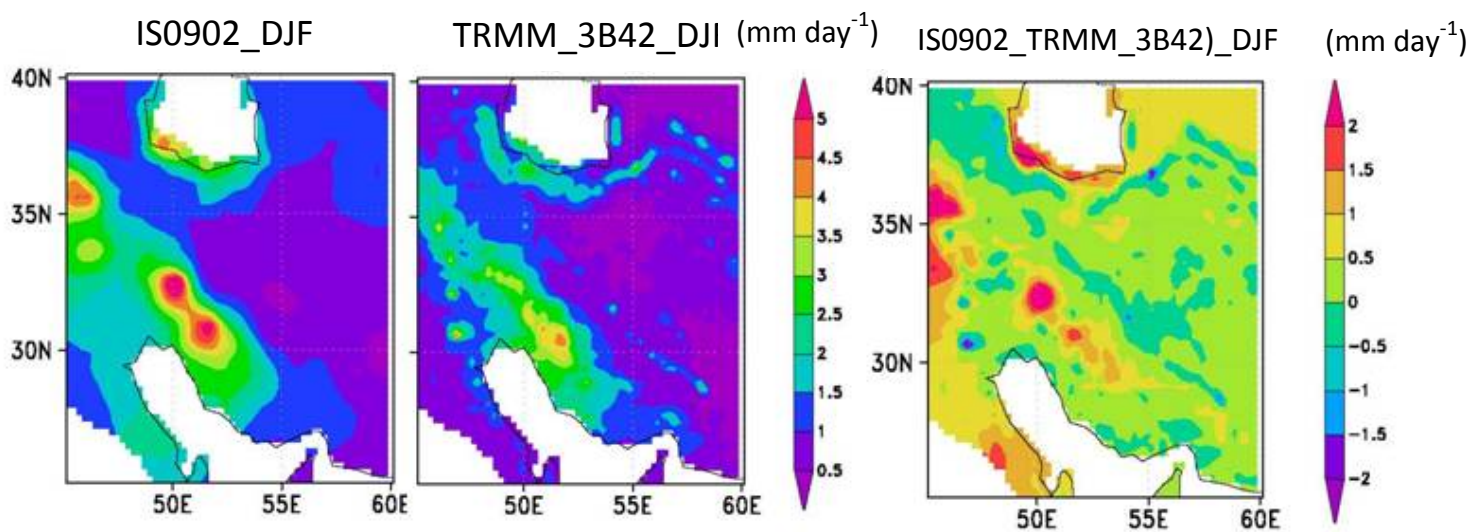

Fig. 6. Comparison of mean seasonal precipitation in IS0902 $\left(0.25^{\circ} \times 0.25^{\circ}\right)$ and TRMM $3 B 42\left(0.25^{\circ} \times 0.25^{\circ}\right)$ for the winter season in the time period 1998-2006. (a) IS0902 (mm day ${ }^{-1}$ ) and (b) TRMM_3B42 (mm day $\left.{ }^{-1}\right)$, (c) Difference in mean seasonal precipitation between IS0902 and TRMM_3B42 $\left(\mathrm{mm}_{\text {day }}{ }^{-1}\right)$. DJF $=$ December, January and February.
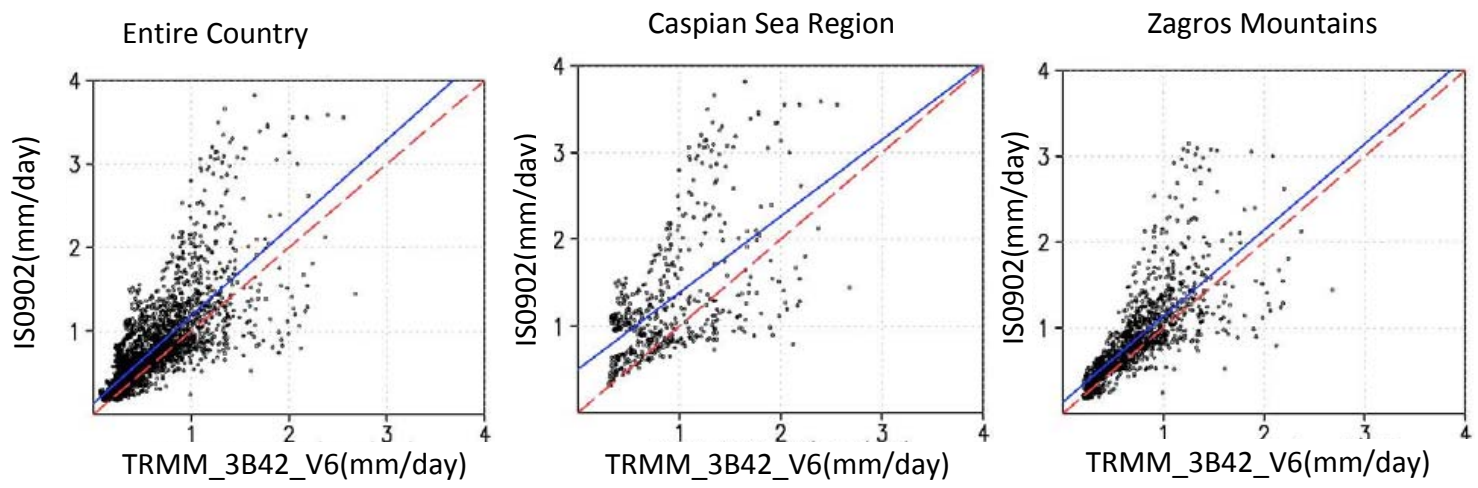

Fig. 7. Scatter plots of annual average of rainfall from IS0902 versus TRMM_3B42 for each $0.25^{\circ} \times 0.25^{\circ}$ grid cell (a) the entire country, (b) the Caspian Sea Region, (c) the Zagros Mountains.

\subsection{Interannual comparison}

Figure 8 shows a comparison between time series of monthly areal average of precipitation (hereafter MAAP) over Iran $\left(25^{\circ}-40^{\circ} \mathrm{N}, 45^{\circ}-60^{\circ} \mathrm{E}\right)$ in IS0902 and TRMM_3B42_V6 from 1998 to 2006. The fluctuations in variation of MAAP in IS0902 and TRMM-3B42 accord well with each other. Maximum MAAP occurs in winter, and minimum rainfall occurs each summer in both IS0902 and TRMM_3B42 (Fig. 9). Comparison of areal rainfall average shows that TRMM_3B42 underestimates rainfall compared with IS0902; for example, the maximum of areal average is $2.5 \mathrm{~mm} \mathrm{day}^{-1}$ in IS0902 and is $2.0 \mathrm{~mm}_{\text {day }}{ }^{-1}$ in TRMM_3B42 for the winter of 2003/2004.

\section{Discussion and conclusion}

One of the most important features of this study is the accordance between observation time in TRMM_3B42 and the synoptic gauges, which is 8 times every three-hours in UTC time. The daily value is derived by summation of the three- hourly observations from 00:00 UTC to 21:00 UTC. A key outcome of the study is the low correlation in rainfall between IS0902 and TRMM_3B42 along the Caspian Sea. A single rain band was evident in the southern part of the Caspian Sea in IS0902, but is separated into two distinct rain bands in TRMM_3B42; one along the Caspian Sea and the other over the Alborz Mountains. This may be related to the complicated topography in the north of Iran and the lack of sufficient rain gauge data over the Alborz Mountains.

We have shown that spatial distribution of mean annual and seasonal precipitation over Iran has two main patterns along the Caspian Sea and the region along the Zagros Mountains. Comparison of spatial distribution of gridded precipitation data and TRMM _3B42 showed good accordance in pattern and amount of precipitation. The scatter plot between mean annual precipitation estimated by TRMM_3B42 and mean annual gridded precipitation using synoptic network data the nine year period from 1998 to 2006 has been derived for the three analysis regions (entire country, Caspian Sea region, Zagros Mountains region) showed had 
Table 1. Statistical parameters of linear regression and spatial correlation coefficient in Fig. 7.

\begin{tabular}{lcccccc}
\hline Figures & $\begin{array}{c}\text { Slope } \\
\text { parameter }\end{array}$ & $\begin{array}{c}\text { Intercept } \\
\text { parameter }\end{array}$ & $\begin{array}{c}\text { Number of } \\
\text { samples }\end{array}$ & $\begin{array}{c}\text { Bias } \\
\text { (TRMM-IS0902) }\end{array}$ & $\begin{array}{c}\text { Standard } \\
\text { deviation }\end{array}$ & $\begin{array}{c}\text { Spatial } \\
\text { correlation } \\
\text { coefficient }\end{array}$ \\
\hline Fig. 7a & 1.05 & 0.13 & 3065 & -0.17 & 0.33 & $0.77^{*}$ \\
Fig. 7b & 0.88 & 0.49 & 502 & -0.39 & 0.60 & $0.57^{*}$ \\
Fig. 7c & 1.01 & 0.14 & 1300 & -0.15 & 0.33 & $0.75^{*}$ \\
\hline
\end{tabular}

* denotes significance level of derived spatial correlation is $99 \%$.

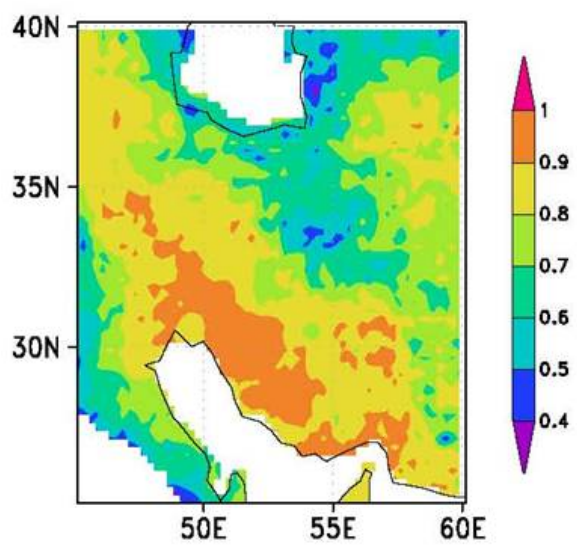

Fig. 8. Spatial distribution of temporal correlation of average annual rainfall in IS0902 and TRMM_3B42 from 1998 to 2006.

spatial correlation coefficients of $0.77,0.57,0.75$, respectively. TRMM(3B42) underestimated precipitation by 0.17 , 0.39 and $0.15 \mathrm{~mm}^{-1 a y^{-1}}$, respectively.

The calculated correlation coefficients are in accordance with Xie et al. (2007), who e derived correlation coefficients of $\sim 0.7$ between the Chinese gauge-based daily precipitation and satellite estimates based on TRMM_3B42. The spatial distribution of temporal correlation coefficient between mean annual precipitation of IS0902 and TRMM_3B42 is 0.8 in the Zagros Mountains region, and 0.6 along the Caspian Sea and in the desert regions.

Future research will compare high-resolution gridded precipitation (IS0902) data with other satellite data such as PERSSIAN, and CMORPH further determine the optimum remote-sensing information to combine with surface observations of precipitation. It will also be necessary to merge gridded surface-based rain gauge data and space-based rainfall estimates to achieve more accurate monitoring of precipitation over Iran.

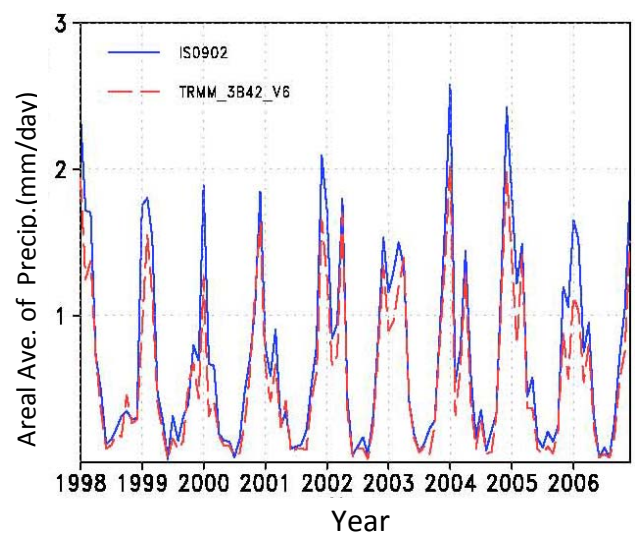

Fig. 9. Comparison of monthly areal precipitation average over Iran $\left(25^{\circ}-40^{\circ} \mathrm{N}, 45^{\circ}-60^{\circ} \mathrm{E}\right)$ in IS0902 (blue solid line) and TRMM_3B42 (red dashed line) from 1998 to 2006.

Acknowledgements. This work contributes to the Asian Precipitation -Highly Resolved Observational Data Integration Towards Evaluation of the Water Resources (APHRODITE's Water Resources) project, which is supported by the Global Environment Research Fund (B-062) of the Ministry of the Environment of Japan. We would like to express special thanks and deep appreciation to Osamu Arakawa and Kenji Kamiguchi from the Meteorological Research Institute (MRI) of Japan Meteorology Agency (JMA) for providing monthly TRMM_3B42 data and programming tools used this study.

Edited by: S. C. Michaelides

Reviewed by: two anonymous referees

\section{References}

Golestani Y., Noorian A. M., and Hudak, D. R.: Design considerations for the two C- and one S-band doppler weather radars in the Islamic Republic of Iran, Phys. Chem. Earth (B), 25, 10-12, 991-994, 2000.

Gruber, A. and Levizzani, V.: Assessment of Global Precipitation Products, A project of the World Climate Research Programme Global Energy and Water Cycle Experiment (GEWEX) radiation panel, WCRP Report No. 128, WMO/TD No. 1430, 50 pp, 2008.

Huffman, G. J., Adler, R. F., Stocker, E. F., Bolvin, D. T., and Nelkin, E. J.: Analysis of TRMM 3-hourly multi-satellite pre- 
cipitation estimates computed in both real and post-real time. Preprints, 12th Conf. on Satellite Meteorology and Oceanography, Long Beach, CA, Amer. Meteor. Soc., CD-ROM, P4.11, 2004.

Huffman G. J.: IPWG algorithm documentation for 3B42V6, 2006, available at: http://disc.gsfc.nasa.gov/precipitation/ documentation/TRMM_README/TRMM_3B42_readme.shtml , last access: 2009.

Huffman, G. J., Adler, R. F., Bolvin, D. T., Gu, G., Nelkin, E. J., Bowman, K. P., Stocker, E. F., and Wolff, D. B.: The TRMM Multi satellite Precipitation Analysis (TMPA): Quasiglobal, multiyear, combined-sensor precipitation estimates at fine scales. J. Hydrometeorol., 8, 38-55, 2007.

Huffman, G. J. and Bolvin, D. T.: TRMM and other data precipitation data set documentation (TRMM 3B42_3B43_doc), laboratory for atmospheres, NASA Goddard space flight center and science systems and applications, Inc., , 2008, available at: ftp: //meso-a.gsfc.nasa.gov/pub/trmmdocs/3B42_3B43_doc.pdf, last access: 2009.

Javanmard, S., Yagagai, A., Nodzu, M. I., Kawamoto, H., Jamali, J. B., Kamiguchi, K., and Arakawa, O.: Improvement of daily gridded precipitation data using synoptic observation data over Iran, Jpn. Meteorol. Soc., Spring meeting, Tsukuba, 28-31 May 2009.

NASDA: TRMM data users handbook, national space development agency of Japan, Earth observation center), 2001, available at: www.eorc.jaxa.jp/TRMM/document/text/handbook_e. pdf, last access: 2009.

Joyce, R. J., Janowiak, J. E., Arkin, P. A., and Xie, P.,: CMORPH: A method that produces global precipitation estimates from passive microwave and infrared data at high spatial and temporal resolution, J. Hydrometeorol., 5, 487-503, 2004.

Mitchell, T. D. and Jones, P. D., An improved method of constructing a database of monthly climate observations and associated high-resolution grids, Int. J. Climatol., 23, 693-712, 2005.

New, M., Hulme, M., and Jones, P.: Representing twentieth-century space-time climate variability, Part II: Development of 190196 monthly grids of terrestrial surface climate, J. Climate, 1(3), 2217-2238, 2000.
Schulz, J., Albert, P., Behr, H.-D., Caprion, D., Deneke, H., Dewitte, S., Dürr, B., Fuchs, P., Gratzki, A., Hechler, P., Hollmann, R., Johnston, S., Karlsson, K.-G., Manninen, T., Müller, R., Reuter, M., Riihelä, A., Roebeling, R., Selbach, N., Tetzlaff, A., Thomas, W., Werscheck, M., Wolters, E., and Zelenka, A.: Operational climate monitoring from space: the EUMETSAT Satellite Application Facility on Climate Monitoring (CM-SAF), Atmos. Chem. Phys., 9, 1687-1709, doi:10.5194/acp-9-1687-2009, 2009.

Shepard, D.: A two dimensional interpolation function for irregularly spaced data, Proc. 23th National Conf. of the Assoc. for Computing Machinery, Princeton, NJ, ACM, 517-524, 1968.

Schneider, U., Fuchs, T., Meyer-Christoffer, A., and Rudolf, B.: Global precipitation products of the Global Precipitation Cetre (GPCC), Deutscher Wetterdienst, Offenbach a. M., Germany, 2008.

Sorooshian, S., Hsu, K. L., Gao, X., Gupta, H. V., Imam, B., and Braithwaite, D.: Evaluation of PERSIANN system satellitebased estimates of tropical rainfall, B. Am. Meteorol. Soc., 81, 2035-2046, 2000.

Turk, F. J, Ebert, E. E., Sohn, B. J., Oh, H. J., Levizzani, V., Smith, E. A., and Ferraro, R.: Validation of an operational global precipitation analysis at short time scales. Preprints, 12th Conf. on Satellite Meteorol. and Oceanography, Long Beach, CA, Am. Meteorol. Soc., CD-ROM, J1.2, 2004.

Xie, P., Yatagai, A., Chen, M., Hayasaka, T., Fukushima, Y., Liu, C., and Yang, S.: A gauge-based analysis of daily precipitation over East Asia, J. Hydrometeorol., 8, 607-626, 2007.

Yatagai, A., Xie, P., and Alpert, P: Development of a daily gridded precipitation data for the middle east, Adv. Geosci., 12, 165-170, 2008 , http://www.adv-geosci.net/12/165/2008/.

Yatagai, A., Arakawa, O., Kamiguchi K., Kawamoto H., Nodzu, M. I., and Hamada, A.: A 44-year daily gridded precipitation dataset for Asia based on a dense network of rain gauges, SOLA, 5, 137-140, 2009. 